\title{
DISEMINASI INTEGRASI KEILMUAN JURNALISME PROFETIK DALAM PENGEMBANGAN KURIKULUM JURUSAN JURNALISTIK
}

\author{
Oleh : Firdaus Muhammad \\ Dosen Jurusan Jurnalistik Fakultas Dakwah dan Komunikasi UIN \\ Alauddin Makassar \\ Email : daus_afkar@yahoo.co.id
}

\begin{abstract}
Abstrak
Penelitian ini difokuskan pada diseminasi integrasi keilmuan Jurnalistik Profetik dipertautkan dengan dimensi Islam atau kenabian. Dalam penelitian Jurnalistik Profetik ini, penulis menyajikan perlunya internalisasi dan aktualisasi nilai-nilai Islam bukan semata yang berdasar pada syar'i atau syariat. Kajian Jurnalistik Profetik pada dasarnya masih tergolong baru, karenanya aspek tersebut menarik dikaji. Sementara penekanan dimensi Islamnya justru diinternalisasikan dan diaktualisasikan dalam proses komunikasi tersebut sehingga mampu mewarnai perilaku Jurnalistik Profetik dengan penekanan pada pesanpesan keislaman. Pengembangan kurikulum jurnalistik menjadi aspek penting sebagai respons terhadap perkembangan keilmuan jurnalistik era digital yang terhadang dimensi etika yang acapkali terabaikan. Karenanya, penting dilakukan diseminasi pengembangan jurnalisme profetik.Temuan dalam penelitian ini, kurikulum jurusan jurnalistik masih didominasi muatan jurnalistik bersifat umum. Hal itu belum berimbang dengan tuntutan terhadap alumni jurusan jurnalistik UIN memiliki perbedaan pada karakter penulisan berita. Integrasi keilmuan jurnalistik dengan ilmu-ilmu keislaman di FDK-UIN belum terwujud, ditandai mata kuliah jurnalsitik secara parsial. Tidak ada mata kuliah jurnalistik untuk penguatan SDM jurnalis Islami sesuai visi-misi jurusan, kecuali mata kuliah jurnalisme profetik yang posisinya sebatas mata kuliah pilihan. Rekomendasi penelitian ini, jurusan jurnalistik harus melakukan revisi kurikulum untuk penguatan jurusan yang melahirkan jurnalis Islami. Alumni yang dilahirkan selama ini belum memenuhi kreteria tersebut.
\end{abstract}

\section{Keyword :}

Jurnalisme Profetik, Integrasi Keilmuan, Jurusan Jurnalistik FDK

\section{A. PENDAHULUAN}

Penelitian ini merupakan salah satu mata kuliah dalam jurusan jurnalistik dengan nama mata kuliah: Jurnalisme Profetik dengan mengintegrasikan ilmu jurnalistik dan keislaman yang berpijak pada nilai ketaladanan nabi. Yakni, mengaktualisasikan nilai-nilai Islam yang selama ini tidak dikaji dalam Jurnalistik Profetik pada umumnya.

Nilai-nilai Islam yang hendak dikaji, diantaranya, mengulas dimensi nilai-nilai keilahiyah dan profetik. Aspek ini dianggap penting untuk memberi warna keislaman dalam kajian Jurnalistik Profetik sehingga menjadi digagas Jurnalistik Profetik. Dasar keilmuannya senafas dengan spirit UIN mengembangkan islamisasi keilmuan. 
Penelitian ini difokuskan pada dimensi keislaman dalam karya jurnalistik. Hal ini dianggap urgen sebab selama ini, Jurnalistik Profetiksedikitpun tidak dipertautkan dengan dimensi Islam. Sementara nilai-nilai Islam diniscayakan untuk diaktualisasikan dalam kehidupan umat. Dalam penelitian Jurnalistik Profetik ini, penulis menyajikan perlunya internalisasi dan aktualisasi nilai-nilai Islam bukan semata yang berdasar pada syar'i atau syariat. Inti dari komunikasi adalah pada pesan, dengan demikian penekananannya pada pesan-pesan keislaman dalam media.

Kajian Jurnalistik Profetik pada dasarnya masih tergolong baru, karenanya aspek tersebut menarik dikaji. Sementara penekanan dimensi Islamnya justru diinternalisasikan dan diaktualisasikan dalam proses komunikasi tersebut sehingga mampu mewarnai perilaku Jurnalistik Profetik dengan penekanan pada pesan-pesan keislaman. Dengan demikian, Jurnalistik Profetik ini berpijak pada Islam dengan umat Islam dalam menyuarakan kemaslahatan mereka sehingga agenda-agenda umat Islam.

Dalam proses pengembangan kurikulum Jurusan Jurnalistik Fakultas Dakwah dan Komunikasi UIN Alauddin Makassar, maka mata kuliah Jurnalisme Profetik merupakan salah satu mata kuliah yang amat penting untuk dipelajari oleh mahasiswa Jurusan Jurnalistik, baik dalam lingkungan perguruan tinggi Islam maupun perguruan tinggi umum.

Sifat mata kuliah ini adalah wajib diikuti oleh seluru mahasiswa dalam jurusan ini. Penyebabnya adalah karena Jurusan Jurnalistik pada umumnya akan mencetak wartawan yang handal dalam meliput dan menulis berita yang bertanggung jawab sesuai kode etik institusi para jurnalis juga nilai-nilai kenabian. Aspek ini hampir belum dikenal di dunia jurnalis yang menerapkan misi kenabian dalam pemberitaan.

Perkembangan media cetak saat ini memanglah mengalami tantangan yang cukup berat, karena ia berhadapan dengan sumber informasi lainnya yang memberikan berbagai kemudahan dan kecepatan penyampaian pesan kepada khalayak pembaca. Misalnya media elektronik seperti televisi dan radio.

Apalagi hadirnya media online yang condong menggeser keberedaan media cetak, namun menghawatirkan karena banyak yang mengendalkan kecepatan lalu mengabaikan ketepatan, berita tanpa tabayyun, mengarah pada provokasi karena berita tidak memenuhi unsur-unsur pemberitaan yang profesional. 
Terlebih dalam satu dekade terakhir, munculnya media online yang sangat banyak jumlah dan variasinya, semakin menambah persaingan antara komponen komunikasi massa dalam menyebarluaskan berita. Sebab media elekronik dan media online lebih mudah diakses dan lebih menarik minat khalayak. Hal ini terjadi karena kedua jenis media ini, mampu menyesuaikan dengan kebutuhan informasi dari khalayak secara cepat dan tepat. Hal ini didukung perilaku masyarakat yang lebih memiliki mengakses media online.

Kondisi seperti inilah yang menjadi tantangan bagi media cetak. Dalam beberapa aspek tidak bisa dipungkiri bahwa media cetak mengalami keterbatasan-keterbatasan, terutama dari aspek kecepatan dan ketepatannya. Namun demikian, penggunaan media cetak oleh khalayak masih akan tetap diperlukan, karena tidak semua individu memiliki persepsi yang sama dalam menerima pesan melalui media elektronik maupun media online. Beberapa kelebihan yang ada pada media cetak antara lain adalah pesannya memiliki makna yang lebih dalam dan penyajian informasinya lebih luas.

Hal inilah yang menjadi tantangan sekaligus peluang bagi mahasiswa Jurusan Jurnalistik yang kelak akan menjadi seorang jurnalis atau wartawan. Melalui mata kuliah ini, mahasiswa akan memperoleh gambaran tentang posisi media cetak pada masa kini dan peluangnya untuk masa yang akan datang. Mahasiswa diharapkan dapat mengembangkan pemikiran yang lebih luas untuk mempertahankan eksistensi media cetak. Lebih daripada itu, melalui mata kuliah ini, mahasiswa diharapkan timbulkan inspirasi baru yang dapat dijadikan pedoman dalam mengembangan usaha penerbitan media cetak. Mereka dituntut profesioanl dan juga memiliki misi kenabian.

Dalam mata kuliah ini, mahasiswa akan mempelajari pokok-pokok pikiran tentang media cetak dan online . Antara lain adalah menyangkut media cetak sebagai media massa, pembicaraan tentang fungsi dan peranan media cetak saat ini, proses peliputan dan penulisan berita dalam media cetak, penerapan etika sebagai seorang jurnalis, prosedur dan bekal kerja dalam pelaksanaan liputan peristiwa, tantangan dan peluang media pada masa yang akan dating dengan berbagai problematikanya.

Penelitian ihwal jurnalisme profetik merupakan bagian diseminasi keilmuan melalui mata kuliah ini juga akan menjadi salah satu kesempatan bagi mahasiswa untuk memperkaya pengetahuan dan wawasan yang lebih luas lagi dengan profesi jurnalistik yang lebih berkarakter. Menjadi jurnalis yang membawa misi profetik. 


\section{B. Rumusan Masalah}

Berdasarkan uraian latar belakang masalah di atas, masalah fokus penelitian ini adalah diseminasi integrasi keilmuna jurnalisme profetik dalam pengembangan kurikulum jurusan jurnalistik. Peneliti memilih tiga sub pertanyaan penelitian yakni:

1. Bagaimana proses integrasi dan diseminasi keilmuan jurnalisme profetik?

2. Bagaimana artikulasi jurnalisme profetik untuk penguatan mata kuliah pada jurusan Jurnalistik di FDK UIN Alauddin?

3. Bagaimana upaya jurusan jurnalistik melakukan inovasi kurikulum melalui mata kuliah jurusan jurnalistik?

\section{Tujuan Penelitian}

Penelitian ini bertujuan untuk mengungkapkan artikulasi diseminasi jurnalisme profetik sebagai salah satu mata kuliah yang amat penting untuk dipelajari oleh mahasiswa Jurusan Jurnalistik, baik dalam lingkungan fakultas dakwah dan komunikasi maupun lingkungan UIN secara umum. Sifat mata kuliah ini adalah wajib diikuti oleh seluruh mahasiswa dalam jurusan ini. Penyebabnya adalah karena jurusan jurnalistik pada umumnya akan mencetak wartawan yang handal dalam meliput dan menulis berita yang bertanggung jawab sesuai kode etik institusi para jurnalis juga nilai-nilai kenabian.

Penelitian ini membahas proses integrasi dan diseminasi keilmuan jurnalisme profetik. Kemudian menjelaskan artikulasi jurnalisme profetik untuk penguatan mata kuliah pada jurusan Jurnalistik di FDK UIN Alauddin. Selain itu, penelitian ini juga bertujuan menjelaskan upaya jurusan jurnalistik melakukan inovasi kurikulum melalui mata kuliah jurusan jurnalistik.

\section{Manfaat Penelitian}

Kegunaan ilmiah, penelitian ini diharapkan dapat memberikan referensi rujukanrujukan pada pengembangan ilmu pengetahuan, khususnya yang terkait jurnalisme profetik maupun pada diseminasi gagasan maupun kiprah dalam pengembangan keilmuan jurnalisme profetik Adapun kegunaan praktis, sebagai upaya mengembangan keilmuan jurnalisme 
profetik menjadi komitmen membangun basis keilmuan bidang jurnalistik yang memiliki nilai-nilai kenabian dalam konteks dakwah.

Sementara itu, teknik pengumpulan data dalam penelitian, adapun teknik pengumpulan data yang dipakai dalam penelitian ini, yakni:

Observasi pada jurusan jurnalistik terutama dalam mendalami kurikulum yang diajarkan selama ini.

1. Melakukan wawancara secara efektif dengan pimpinan FDK, ketua jurusan, dosen, mahaiswa hingga alumni.

2. Analisis dokumen, digunakan untuk memperoleh data sekunder yaitu kajian keilmuan jurnalisme profetik yang memadukan atau mengintegrasikan jurnalistik dan dakwah.

3. Riset kepustakaan (library reasearch), yaitu dengan mengumpulkan rujukan-rujukan dari berbagai sumber seperti buku, surat kabar, dan keterangan-keterangan ilmiah lainnya yang berhubungan dengan masalah yang diteliti.

\section{B. PEMBAHASAN HASIL PENELITIAN}

\section{Integrasi dan diseminasi keilmuan jurnalisme profetik.}

Penelitian ini berupaya menjawab sejumlah pertanyaan yang diajukan dalam rumusan masalah dalam penelitian ini. Jawaban-jawaban penting diperoleh sepanjang penelitian yang urgen untuk dijadikan acuan dalam pengembangan jurusan jurnalistik melalui penguatan mata kuliah jurnalisme profetik.

Proses Interdisipliner jurnalistik profetik dan karya jurnalistik umum menjadi bagian komitmen pengembangan keilmuan dan praksis. Dalam hal ini, jurnalistik profetik dipandang sebagai salah satu bagian dari bentuk kegiatan dakwah, juga dilihat sebagai kegiatan komunikasi.

Hal ini sangat penting mengingat tantangan umat Islam pada saat ini dan masa yang akan datang akan semakin berat sehingga membutuhkan kajian-kajian keilmuan yang berbasis multidisipliner sehingga ilmu jurnalistik diintegrasikan dengan nilai profetik, keislaman atau kenabian. Meningkatnya jumlah mahasiswa fakultas dakwah dan 
komunikasi saat ini salah satu faktornya adalah pengingtegrasian keilmuan dakwah dan komunikasi.

Jurusan jurnalistik menjadi bagian Fakultas Dakwah dan Komunikasi UIN Makassar diharapkan akan lahir ulama yang intelektual atau intelektual yang ulama (dai yang memiliki wawasan agama yang dalam tetapi juga "bersahabat" dengan perkembangan teknologi komunikasi mutakhir). Penyandang identitas seperti itu adalah seseorang yang memiliki ciri-ciri sebagai berikut:

(1) Memiliki kekokohan aqidah dan kedalaman spiritual, (2) keagungan budi pekerti, (3) keluasan ilmu, dan (4) kematangan profesional. Ciri-ciri seperti itu dipandang lebih komplit, meliputi semua potensi yang seharusnya dikembangkan pada diri setiap pemimpin atau khalifah agar benar-benar mampu membangun budaya dan peradaban yang tinggi.

Secara operasional Fakultas Dakwah dan komunikasi UIN Alauddin Makassar dapat digambarkan sebagai berikut:

a) Penampilan (performance) Fisik

Secara fisik kampus Fakultas Dakwah dan Komunikasi UIN Alauddin Makassar sebagai lembaga pendidikan tinggi yang beridentitas dan sekaligus mengembangkan ilmu yang berparadigma Islam harus menampilkan citra yang berwibawa, sejuk rapi dan indah. Kampus Fakultas Dakwah dan Komunikasi UIN Alauddin Makassar harus memberikan kesan sebagai berikut: a). Bersih, rapi, dan indah, b). Modern dan dinamis serta dihuni oleh orang-orang terpilih yang selalu mendekatkan diri kepada Allah, c). Dihuni oleh orang yang memiliki kepekaan tinggi terhadap sesama manusia dan alam lingkungannya, terpercaya dan menjadi tauladan bagi masyarakat.

b). Kelembagaan: a). Memiliki tenaga akademik yang handal dalam pemikiran, penelitian dan berbagai aktivitas ilmiah. b). Memiliki tradisi akademik yang mendorong lahirnya kewibawaan akademik bagi seluruh civitas akademika, c). Memiliki manajemen yang kokoh yang mampu menggerakkan seluruh potensi untuk mengembangkan kreativitas warga kampus, d). Memiliki kemampuan antisipatif masa depan dan bersikap proaktifm e). Memiliki pimpinan yang mampu mengakomodasikan seluruh potensi yang dimiliki menjadi kekuatan penggerak lembaga secara menyeluruh. 


\section{Visi Misi Jurusan Jurnalisitik}

Dalam upaya pengembangan Jurusan jurnalistik, dimulai dengan memantapkan visinya sebagai orientasi pengembangan ke depan. Penyusunan visi dan misi jurusan/program studi Jurnalistik mengacu pada Fakultas. Pelaksanaan penyusunan tersebut melalui mekanisme rapat pimpinan Fakultas Dakwah dan Komunikasi yang di dahului dengan pertemuan jurusan dan dosen jurusan yang diadakan untuk menggodok butir-butir visi, misi dengan kondisi riil pemangku kepentingan yang menjadi input dari Jurusan Jurnalistik Fakultas Dakwah dan Komunikasi UIN Alauddin itu sendiri. ${ }^{1}$

Adapun visi Program Studi Jurnalistik sebagai Pusat Kajian Jurnalistik yang Profesional tahun 2025

Adapaun misi jurusan Jurnalistik :

1. Melaksanakan, Mengembangkan pendidikan dan pengajaran, penelitian dan pengabdian pada masyarakat di bidang jurnalistik.

2. Melaksanakan praktek jurnalistik yang islami dan profesional.

3. Menyiapkan sarjana jurnalistik yang profesional untuk memenuhi kebutuhan masyarakat.

4. Mendorong terwujudnya kerjasama berbagai pihak dalam pelaksanaan Tridarma PT, terutama dalam bidang pengembangan jurnalistik dan media.

Penyusunan visi dan misi program studi dilakukan dengan melibatkan seluruh civitas Program Studi Jurnalistik, dengan mengadakan: workshop penyusunan visi dan misi program studi dengan melibatkan; a). Tenaga administrasi kependidikan, dengan cara diskusi dan rapat di Fakultas dan Program Studi, sebagai masukan bagi pengembangan Program Studi, sehingga dapat diketahui tentang harapan dan persepsi mereka tentang Program Studi Jurnalistik, b). Pimpinan Fakultas, yang memberikan arah pengembangan Fakultas Dakwah dan Komunikasi yang dituangkan dalam rencana strategis Fakultas.

Dengan penetapan visi dan misi Program Studi Jurnalistik yang berkesinambungan diharapkan terjadi pengembangan kualitas yang terintegrasi, yang senantiasa tanggap dan peka terhadap berbagai perubahan, memiliki akutanbilitas, akreditasi dan evaluasi diri sebagai paradigma baru pendidikan tinggi yang tidak hanya bertumpu pada bidang jurnalistik akan tetapi juga dikaitkan dengan bidang-bidang yang lain.

\footnotetext{
${ }^{1}$ Profil Jurusan Jurnalistik Fakultas Dakwah dan Komunikasi Tahun 2017
} 
Dengan demikian perumasan visi dan misi program studi dengan mengaju pada saran dan pendapat dari seluruh stakeholders dalam workshop yang diadakan melalui rapat seluruh pimpinan Fakultas Dakwah dan Komunikasi dan seluruh dosen jurusan. Penetapan visi dan misi dalam bentuk surat keputusan Dekan Fakultas Dakwah dan Komunikasi UIN Alauddin Makassar, sebagai pedoman dalam seluruh pelaksanaan kegiatan di jurusan.

Adapun visi dan misi Jurnalistik sebagai berikut:

a. Visi : Menjadikan Program Studi Jurnalistik sebagai pusat kajian Jurnalistik Islami yang professional tahun 2025

\section{Misi :}

1. Menyelenggarakan pendidikan dan pelatihan jurnalistik

2. Melaksanakan penelitian dan pengabdian masyarakat di bidang jurnalistik.

3. Memanfaatkan dan menerapkan teknologi dan informasi di bidang jurnalistik.

4. Membangun kerjasama dengan institusi media.

\section{c. Tujuan}

1. Program Studi S1 Jurnalistik bertujuan untuk mendidik dan menghasilkan tenaga profesional yang unggul dan mempunyai pengetahuan dan ketrampilan pada hal-hal sebagai berikut:

Menghasilkan sarjana komunikasi yang handal, berkualitas dan profesional terhadap tuntutan globalisasi.

2 Menghasilkan sumberdaya manusia yang mampu menciptakan konsep, pemikiran dan teori aplikatif untuk memecahkan permasalahan dalam perspektif komunikasi dan media.

3 Menciptakan sumberdaya manusia yang mampu berkompetisi di dunia profesional dalam bidang komunikasi dan media baik tingkat lokal, nasional maupun internasional dengan menjunjung tinggi moralitas dan etika serta norma-norma agama dalam mengembangkan ilmu pengetahuan dan teknologi di bidang komunikasi dan media.

4 Menciptakan sumber daya manusia yang mampu menghasilkan karya-karya penelitian yang bermanfaat bagi masyarakat dan terpublikasi. 
5 Menciptakan sumber daya manusia yang tanggap dan mampu menyelesaikan masalah-masalah sosial kemasyarakatan dengan cara-cara yang bujaksana dengan mengedepankan nilai-nilai moral dan akhlak yang mulia. ${ }^{2}$

\section{Kurikulum Jurusan Jurnalistik}

- Etika media dan hukum

- Feature dan Jurnalisme Sastrawi

- Dasar-dasar Jurnalistik

- Teknik Peliputan dan Penulisan Berita

- Jurnalistik Online

- Investigasi reporting

- Bahasa Jurnalistik

- Jurnalistik Siaran

- TV Presenting

- Ekonomi Media

- Fotografi dan Foto Jurnalistik

- Jurnalisme Profetik

- Etika Jurnalis Muslim

- Investigasi Reporting

- Produksi dan Industri Media

- Penelitian Jurnalistik

\section{Artikulasi Jurnalisme profetik untuk penguatan mata kuliah pada jurusan Jurnalistik di FDK UIN Alauddin}

Dalam realitasnya, kurikulum jurusan jurnalistik masih didominasi muatan jurnalistik bersifat umum. Hal itu belum berimbang dengan tuntutan terhadap alumni jurusan jurnalistik UIN memiliki perbedaan pada karakter penulisan berita.

Tercatat mata kuliah jurnalisme profetik merupakan mata kuliah yang baru diterapkan sejak 2016 dalam posisi mata kuliah pilihan sehingga sejumlah alumni sebelumnya tidak mendapatkan mata kuliah tersebut. Sebelumnya, tidak ada mata kuliah yang spesifik bahas dimensi keislaman.

\footnotetext{
${ }^{2}$ Profil Jurusan Jurnalistik Fakultas Dakwah dan Komunikasi Tahun 2017
} 
Kemudian sejak 2018, mulai diperkenalkan mata kuliah etika jurnalis muslim. Mata kuliah ini baru diterapkan 2018 diupayakan untuk mampu mewarnai karakter jurnalis yang menjunjung tinggi etika jurnalis dan etika keislaman. Naba berarti berita, annaba berarti pembawa berita. Aspek profetik dalam karya jurnalistik menjadi keniscayaan terutama dimensi etikanya sebagai jurnalis muslim.

Pendidikan jurnalistik merupakan dasarnya, sebagai wadah yang bernilai strategis guna peningkatan kualitas calon jurnalis. Sebagai misal negara-negara maju (Amerika dan Eropa) memusatkan perhatian dalam peningkatan kualitas jurnalis, melalui sistem pendidikan jurnalistik berbasis perguruan tinggi. Ada yang berbentuk fakultas, jurusan atau program studi, maupun terkonsentrasi dalam satu institut-universitas, serta berbentuk persekolahan (school of journalism). ${ }^{3}$

\section{Upaya jurusan jurnalistik melakukan inovasi kurikulum melalui mata kuliah jurusan jurnalistik.}

Idealnya rekrutmen jurnalis membutuhkan proses yang selektif dan simultan. Ukuran selektif dalam pengertian memenuhi kualifikasi dasar profesi jurnalis. Sebagai yang dirumuskan Dewan Pers, bahwa kesadaran, pengetahuan, dan keterampilan, adalah kualifikasi dasar profesi jurnalis. Karena itu, keniscayaan pendidikan dan pelatihan praktis jurnalistik sebagai sarana peningkatan mutu jurnalis.

Keragaman model pendidikan jurnalistik dan pelatihan praktis jurnalistik, bukan suatu pemilah-milahan yang bersifat monopoli, atau mendiskreditkan potensi lembaga yang satu atas lainnya. Sebab pada dasarnya bertujuan sama memenuhi standar kompetensi jurnalis-wartawan. Dalam pada itu, ada korelasi positif yang bisa dilihat dari keragaman model pendidikan jurnalistik.

Artikulasi dari argumen tersebut di atas hendak menjalin sinergitas antar lembaga pendidikan, terutama lembaga yang mengakomodasi pendidikan dan pelatihan praktis

\footnotetext{
${ }^{3}$ Di AS misalnya; Department of Journalism at the Pennsylvania State University, School of Journalism at Michigan State University, Journalism Institute at New York University, Journalism Programme at Emory University. Di Eropa; London School of Journalism (Inggris), Deutsche Journalistenschule (Jerman), Ecole Supérieure de Journalisme de Paris (Prancis), Faculty of Journalism at Moscow State University (Rusia), dan sebagainya. Disadur dari artikel; Supriyoko., (mantan anggota Dewan Kehormatan PWI Jogjakarta). http://suaraguru.wordpress.com/2010/02/16/sekolah-jurnalistik-indonesia/. (akses 23 November 2018).
} 
jurnalistik. ${ }^{4}$ Namun pada kenyataan, pendidikan jurnalistik berbasis perguruan tinggi, yang diklaim pihak akademisi (untuk tidak mengatakan seluruhnya) sebagai pemasok jurnalis andal-profesional, kompetitif, meragukan beberapa pihak. Bertolak dari pernyataan Nurudin, “... media di Indonesia dengan perkembangannya tidak bisa diimbangi dengan pendidikan formal jurnalistik". 5

Kritik tajam yang logis, sebab sarjana jurnalistik pada umumnya dari lulusan perguruan tinggi, yang riil dilapangan relatif minim dibanding jumlah penerbitan dan penyiaran pers. "Lulusan ... yang ada baru siap latih, belum siap pakai" ujar Nurudin dalam karya tulisnya. ${ }^{6}$ Ketidakmampuan perguruan tinggi dalam menghasilkan lulusan jurnalistik yang handal berimbas pada terbentuknya pilihan untuk memberdayakan calon jurnalis dengan cara alamiah (natural) unscientific.

Upaya-upaya yang dilakukan jurusan jurnalistik FDK UIN Alauddin adalah melakukan diseminasi integrasi melalui kerjasama berbagai lembaga media untuk pengembangan dan penguatan kurikulum. Praktikum di berbagai media adalah wujud komitmen tersebut. Selain itu juga digelar kuliah umum dengan menghadirkanpara pakar di bidang masing-masing. Diantaranya menghadirkan Maman Suherman untuk investigasi reporting dan Zawawi Imron bahas jurnalisme sastrawi.

Proses para mahsiswa dan alumni menjadi jurnalis, melalui pendidikan dasar, misalnya pelatihan praktis jurnalistik, atau sistem pengembangan karir mediasi, salah satunya melalui sekolah jurnalistik yang dikerjasamakan dengan AJI Kota Makassar. Terlepas dari penting atau tidaknya jurnalis melalui proses pendidikan, persoalannya mengapa sarjana jurnalistik senjang dengan dunia kerjanya, bagaimana eksistensi perguruan tinggi sebagai pencetak generasi intelektual yang andal dan produktif.

Problematika yang dihadapi misalnya, kekurangan pasokan jurnalis profesional untuk industri pers ini salah satunya disebabkan belum mampunya perguruan tinggi menghasilkan tenaga siap kerja di bidang pers. Karena itu, ada pergeseran orientasi yang

\footnotetext{
Berita Dewan Pers., loc. cit. h. 1-2.

${ }^{5}$ Nurudin., Jurnalisme Masa Kini, (Jakarta; Rajawali Pers, 2009), h. 143.

${ }^{6} I b i d$, h. 145 .
}

${ }^{4}$ Bentuk sinergitas tersebut diwujudkan menjadi Asosiasi Pendidikan Jurnalisme Indonesia (APJI), atas prakarsa Program S-1 Reguler Ilmu Komunikasi FISIP-UI, bekerjasama dengan Serikat Penerbit Suratkabar (SPS) Pusat, dan difasilitasi oleh Dewan Pers dan Unesco (Yogyakarta, 15 April 2007). Etika; 
sudah berlangsung cukup lama di kalangan perusahaan media, bahwa kebutuhan terhadap jurnalis tidak lagi harus berasal dari lulusan disiplin ilmu jurnalistik. ${ }^{7}$

Mengurai kendala internal dan eksternal perguruan tinggi dalam hal pendidikan jurnalistik merupakan jawaban atas pertanyaan mengapa dari sekian banyak (untuk tidak menyebut seluruhnya) lulusan sarjana jurnalistik maupun ilmu komunikasi kurang diberdayakan oleh lembaga penerbitan dan penyiaran pers. Hasil penelitian Thomas Hanitzsch menyatakan; ... kurikulum nasional menghambat penyelenggaraan pendidikan jurnalistik, tidak ada interaksi antara pendidikan jurnalistik dan industri media, dan tidak dilengkapi sarana teknologi atau laboratorium yang kurang memadai. ${ }^{8}$

Kurikulum pendidikan jurnalistik pada perguruan tinggi, yaitu, multi-disiplin keilmuan dan terapan jurnalistik, yang ditunjang dengan sarana dan prasarana mutakhir teknologi informasi-media massa. Misalnya, perangkat stasiun radio, televisi, laboratorium foto atau sinematograpi, pers mahasiswa dan wadah empiris jurnalistik sebagai miniatur lembaga pers. ${ }^{9}$ Keterandalan pendidikan jurnalistik di perguruan tinggi pada umumnya tidak lepas dari faktor SDM. Dalam hal ini tenaga pengajar atau dosen pengampu berkualifikasi pendidikan jurnalistik, atau publisistik dan komunikasi, notabene mereka mendalami secara komprehensif keilmuan jurnalistik.

\section{Kesimpulan}

Pengembangan kurikulum jurnalistik menjadi aspek penting sebagai respons terhadap perkembangan keilmuan jurnalistik era digital yang terhadang dimensi etika yang acapkali terabaikan. Karenanya, penting dilakukan diseminasi pengembangan jurnalisme profetik.

Temuan dalam penelitian ini, kurikulum jurusan jurnalistik masih didominasi muatan jurnalistik bersifat umum. Hal itu belum berimbang dengan tuntutan terhadap alumni jurusan jurnalistik UIN memiliki perbedaan pada karakter penulisan berita.

\footnotetext{
${ }^{7}$ Etika; Berita Dewan Pers., loc. cit, h. 1-2.
}

${ }^{8}$ Thomas Hanitzsch dalam penelitian "Rethinking Journalism Education in Indonesia; Nine Theses". Dari Universitas Ilmenau-Jerman, kandidat Doktor Universitas Gadjah Mada, dan pernah meneliti tentang pendidikan jurnalistik di Indonesia (Harsono; 2004), Nurudin., op. cit, h. 146-149.

${ }^{9}$ Pers mahasiswa, Washilah (tabloid dan stasiun radio), Syi'ar (stasiun radio), yang menjadi wadahpraktikum mahasiswa di bidang jurnalistik. Sebuah studi pendahuluan yang ditelusuri dari berbagai referensi, wawancara, dan tinjauan langsung ke lokasi setempat.. 
Tercatat mata kuliah jurnalisme profetik merupakan mata kuliah yang baru diterapkan sejak 2016 dalam posisi mata kuliah pilihan sehingga sejumlah alumni sebelumnya tidak mendapatkan mata kuliah tersebut. Sebelumnya, tidak ada mata kuliah yang spesifik bahas dimensi keislaman.

Kemudian sejak 2018, mulai diperkenalkan mata kuliah etika jurnalis muslim. Mata kuliah ini baru diterapkan 2018 diupayakan untuk mampu mewarnai karakter jurnalis yang menjunjung tinggi etika jurnalis dan etika keislaman. Naba berarti berita, annaba berarti pembawa berita. Aspek profetik dalam karya jurnalistik menjadi keniscayaan terutama dimensi etikanya sebagai jurnalis muslim.

1. Integrasi keilmuan jurnalistik dengan ilmu-ilmu keislaman di FDK-UIN belum terwujud, ditandai mata kuliah jurnalsitik secara parsial.

2. Tidak ada mata kuliah jurnalistik untuk penguatan SDM jurnalis Islami sesuai visimisi jurusan, kecuali mata kuliah jurnalisme profetik yang posisinya sebatas mata kuliah pilihan.

3. Rekomendasi penelitian ini, jurusan jurnalistik harus melakukan revisi kurikulum untuk penguatan jurusan yang melahirkan jurnalis Islami. Alumni yang dilahirkan selama ini belum memenuhi kreteria tersebut.

Dalam beberapa aspek tidak bisa dipungkiri bahwa dunia jurnbalstik mengalami tantangan baru dengan hadirnya media online yang juga menjadi tantangan menjaga dimensi etika kejurnalistikan. Selama ini, penggunaan media cetak oleh khalayak masih akan tetap diperlukan, karena tidak semua individu memiliki persepsi yang sama dalam menerima pesan melalui media elektronik maupun media online yang diperhadapkan dengan jurnalisame profetik.

Problem pengembangan jurnalisme profetik dalam jurusan jurnalistik karena sifatnya pilihan. Mahasiswa masih dominan belajar jurnalistik umum. Sementara, peluang bagi mahasiswa Jurusan Jurnalistik yang kelak akan menjadi seorang jurnalis atau wartawan.

Melalui mata kuliah ini, mahasiswa akan memperoleh gambaran tentang posisi media cetak pada masa kini dan peluangnya untuk masa yang akan datang. Mahasiswa diharapkan dapat mengembangkan pemikiran yang lebih luas untuk mempertahankan eksistensi media cetak. Lebih daripada itu, melalui mata kuliah ini, mahasiswa diharapkan 
timbulkan inspirasi baru yang dapat dijadikan pedoman dalam mengembangan usaha penerbitan media cetak.

\section{Implikasi dan Rekomendasi}

Dalam mata kuliah ini, mahasiswa akan mempelajari pokok-pokok pikiran tentang etika jurnalistik muslim dan jurnalisme profetik. Antara lain adalah menyangkut media cetak sebagai media massa, pembicaraan tentang fungsi dan peranan media cetak saat ini, proses peliputan dan penulisan berita dalam media cetak, penerapan etika sebagai seorang jurnalis, prosedur dan bekal kerja dalam pelaksanaan liputan peristiwa, tantangan dan peluang pada jurusan jurnalistik di lingkungan UIN Alauddin Makassar, khususnya di FDK. 


\section{DAFTAR PUSTAKA}

Alamsyah dkk, Profil Jurusan Jurnalistik Fakultas Dakwah dan Komunikasi Makassar; Tahun 2017

Department of Journalism at the Pennsylvania State University, School of Journalism at Michigan State University, Journalism Institute at New York University, Journalism Programme at Emory University.

Supriyoko., (mantan anggota Dewan Kehormatan PWI Jogjakarta).

http://suaraguru.wordpress.com/2010/02/16/sekolah-jurnalistik-indonesia/. (akses 23 November 2018).

Asosiasi Pendidikan Jurnalisme Indonesia (APJI), atas prakarsa Program S-1 Reguler Ilmu Komunikasi FISIP-UI, bekerjasama dengan Serikat Penerbit Suratkabar (SPS) Pusat, dan difasilitasi oleh Dewan Pers dan Unesco (Yogyakarta, 15 April 2007).

Nurudin., Jurnalisme Masa Kini, (Jakarta; Rajawali Pers, 2009), h. 143.

Thomas Hanitzsch dalam penelitian "Rethinking Journalism Education in Indonesia; Nine Theses". Universitas Ilmenau-Jerman, 2004.

Pers mahasiswa, Washilah (tabloid dan stasiun radio), Syi'ar (stasiun radio), yang menjadi wadah-praktikum mahasiswa di bidang jurnalistik. 